\title{
PERSEPSI GURU PADA SOAL OPEN ENDED
}

\begin{tabular}{|c|c|c|c|}
\hline \multicolumn{4}{|c|}{$\begin{array}{c}\text { Nurhasanah } \\
\text { STIT Sunan Giri Bima } \\
\text { nur.hasanah100194599@gmail.com }\end{array}$} \\
\hline Submit & Received & Edited & Published \\
\hline 17 Des. 2021 & 20 Des. 2021 & 26 Des. 2021 & 31 Des. 2021 \\
\hline
\end{tabular}

\begin{abstract}
The ability to think creatively which is the goal of $\mathrm{K} 13$ is one of the desired skills in the world of work so it must be instilled while still in school because creativity determines human resources to improve human welfare. Creative thinking requires convergent and divergent thinking, problem finding and problem solving and is closely related to openended thinking. This study aims to determine the teacher's perception of open ended questions. The subjects of this study were four SMK mathematics teachers. The approach used is a qualitative approach. The results of this study were that there were two teachers who had developed and used open-ended questions and two teachers had never developed and used open-ended questions. The main obstacle for teachers who have developed is the difficulty in finding topics that are meaningful and easy to develop. The obstacle for teachers who have never developed is that teachers do not believe in students because students still have difficulty working on easy questions and teachers still have low interest in the development and use of open ended questions.
\end{abstract}

Keywords : teacher's perception, open ended

\begin{abstract}
ABSTRAK
Kemampuan berpikir kreatif yang merupakan tujuan dari K13 adalah salah satu skill yang dikehendaki dalam dunia kerja sehingga sudah harus ditanamkan saat masih bersekolah karena kreativitas menentukan sumber daya manusia untuk meningkatkan kesejahteraan manusia. Berpikir kreatif membutuhkan pemikiran konvergen dan divergen, penemuan masalah dan pemecahan masalah dan sangat dekat hubungannya dengan open-ended. Penelitian ini bertujuan untuk mengetahui persepsi guru pada soal open ended. Subjek dari penelitian ini adalah empat orang guru matematika SMK. Pendekatan yang digunakan adalah pendekatan kualitatif. Hasil dari penelitian ini adalah terdapat dua guru yang sudah pernah mengembangkan dan menggunakan soal open ended dan dua guru belum pernah mengembangkan dan menggunakan soal open ended. Kendala dalam dari guru yang pernah mengembangkan adalah kesulitan dalam menemukan topik yang bermakna serta mudah untuk dikembangkan. Kendala bagi guru yang belum pernah mengembangkan adalah guru belum percaya kepada siswa karena siswa masih mengalami kesulitan dalam mengerjakan soal mudah serta guru masih memiliki minat yang rendah terhadap pengembangan dan penggunaan soal open ended.
\end{abstract}

Kata Kunci : Persepsi Guru, Open Ended

\begin{tabular}{|c|c|c|c|c|c|}
\hline Volume & Nomor & Edisi & P-ISSN & E-ISSN & Halaman \\
12 & 2 & Deseber 2021 & 20857365 & $2722-3027$ & $75-84$ \\
\hline
\end{tabular}




\section{PENDAHULUAN}

Kurikulum 2013 saat ini bertujuan buat mempersiapkan insan Indonesia supaya mempunyai kemampuan hayati menjadi eksklusif dan masyarakat negara yang beriman, produktif, kreatif, inovatif dan afektif dan bisa berkontribusi di kehidupan bermasyarakat, berbangsa, bernegara dan peradaban global ${ }^{1}$. Kemampuan berpikir kreatif yang merupakan tujuan dari K13 adalah salah satu skill yang dikehendaki dalam dunia kerja sehingga sudah harus ditanamkan saat masih bersekolah karena kreativitas menentukan sumber daya manusia untuk meningkatkan kesejahteraan manusia ${ }^{2}$. Guru umumnya hanya berpikir bahwa logika merupakan hal primer yg dibutuhkan pada belajar matematika serta kreativitas tidak krusial pada belajar matematika ${ }^{3}$ padahal kreativitas adalah salah satu kompetensi dalam kurikulum 2013. Kreativitas membutuhkan pemikiran konvergen dan divergen, penemuan masalah dan pemecahan masalah, ekspresi diri, motivasi intrinsik, sikap mempertanyakan sesuatu dan kepercayaan diri ${ }^{4}$. Kreativitas sangat dekat hubungannya menggunakan open-ended. Open ended berpotensi buat berbagi kemampuan berpikir kreatif peserta didik $^{5}$.

Pendekatan open ended mendukung keterlibatan siswa dalam kegiatan belajar di kelas dan mendorong mereka untuk mengeksplorasi dan menyelediki, meningkatkan motivasi, mencari model, berkomunikasi serta mendiskusikan dan belajar untuk mengidentifikasi ${ }^{6}$. Pendekatan open-ended memungkinkan siswa menemukan gagasan yang berbeda, tidak biasa dan orisinil padahal jika guru benar-benar mengamati divergent thinking siswa, guru akan melihat perbedaan dan bagaimana pola ide-ide yang dibuat siswa ${ }^{78}$

1 Kemendikbud, "Permendikbud Nomor 70 Tahun 2013 Tentang Kerangka Dasar Dan Struktur Kurikulum Sekolah Menenggah Kejuruan/Madrasah Aliyah Kejuruan,” no. Standar Penilaian Pendidikan (2016): 1-234.

2 Ali Mahmudi, "Mengukur Kemampuan Berpikir Kreatif Matematis," In Konferensi Nasional Matematika XV UNIMA Manado. (2010).

${ }^{3}$ Erkki Pehkonen, "Fostering of Mathematical Creativity" (1983): 63-67.

${ }^{4}$ Mark A. Runcho, "Creativity as an Educational Objective for Disadvantaged Students," The National Research Center on The Gifted and Talented, no. 9306 (1993).

${ }^{5}$ Yoshihiko Hashimoto, "The Methods of Fostering Creativity through Mathematical Problem Solving," ZDM - International Journal on Mathematics Education 29, no. 3 (1997): 86-87.

${ }^{6}$ Helena P. Osana et al., "The Role of Content Knowledge and Problem Features on Preservice Teachers' Appraisal of Elementary Mathematics Tasks," Journal of Mathematics Teacher Education 9, no. 4 (2006): 347380 .

${ }^{7}$ Runcho, "Creativity as an Educational Objective for Disadvantaged Students."

${ }^{8}$ Karina Pratinuari, "Keefektifan Pendekatan Open-Ended Dengan Pembelajaran Kontekstual Terhadap Kemampuan Berpikir Kreatif," Ujme 2, no. 1 (2013): 105-113. 
Pendekatan open ended tidak membatasi siswa pada sejumlah masalah sehingga mereka dapat menciptakan jawaban dan menjawab lebih banyak pertanyaan ${ }^{9}$. Guru perlu memberi kesempatan kepada siswa untuk menuliskan pemikirannya yang berbeda serta mendiskusikan kreativitas dengan murid mereka. Salah satu hal esensial dari kreativitas adalah orisinalitas karena sangat dibutuhkan sebagai pembeda karya siswa satu dengan yang lainnya ${ }^{1011}$.

Selain berpikir kreatif, berpikir kritis juga dibutuhkan dalam pembelajaran Matematika untuk menghadapi soal pemecahan masalah namun siswa belum terbiasa untuk menghadapi soal-soal pemecahan masalah dan kurang mampu dalam menuliskan penyelesaiannya sehingga mereka tidak percaya diri dalam menyelesaikan soal tersebut. Hal itu disebabkan karena guru cenderung memberikan soal yang sifatnya konvergen yaitu jawaban dan strategi penyelesaian yang tunggal ${ }^{12}$ selain itu soal yang diberikan adalah soalsoal rutin yang berpedoman pada buku teks dan guru hanya menuntut kemampuan proseduralnya $^{13}$. Guru diharapkan memberikan soal yang sifatnya divergen untuk melatih siswa dalam mengasah kemampuan berpikir kritis dan kreatifnya. Salah satu pendekatan untuk membuat soal dalam bentuk divergen adalah open-ended ${ }^{14}$.

Penelitian yang dilakukan oleh Lambertus, Arapu dan Patih (2013) mengungkapkan bahwa pendekatan open ended dapat meningkatkan tingkat berpikir kreatif matematik pada siswa karena dapat mendorong siswa untuk lebih mengembangkan kreativitasnya dalam menyelesaikan masalah atau soal yang diberikan ${ }^{15}$. Penelitian selanjutnya yang dilakukan oleh Faridah, Isrok'atun dan Aeni (2016) mengungkapkan bahwa pendekatan open ended dapat meningkatkan kemampuan berpikir kreatif matematis dan dapat pula meningkatkan

${ }^{9}$ Hiro Ninomiya and Panpiti Pusri, "The Study of Open-Ended Approach in Mathematics Teaching Using Jigsaw Method,” A Case Study of the Water Beaker Problem 64, no. 2 (2015): 11-22.

10 Firdaus, Abdur Rahman As'ari, and Abd Qohar, "Meningkatkan Kemampuan Berpikir Kreatif Matematis Siswa Sma Melalui Pembelajaran Open Ended Pada Materi Spldv," Jurnal Pendidikan 1, no. 2 (2016): 227-236.

${ }^{11}$ Eric L Mann, "Creativity: The Essence of Mathematics," Journal for the Education of the Gifted 30, no. 2 (2006): 236-260.

12 Hafizah Delyana, "Peningkatan Kemampuan Pemecahan Masalah Matematika Siswa Kelas VII Melalui Penerapan Pendekatan Open Ended," Lemma Vol 2, no. 1 (2015): 26-34.

${ }^{13}$ Ummil Muhsinin, "Pendekatan Open Ended Pada Pembelajaran,” Edu-Math 4, no. 1 (2013): 46-59.

${ }^{14}$ Saniah Djahuno, "Pengembangan Soal-Soal Open-Ended Pada Pokok Bahasan Barisan Dan Deret Bilangan Di Kelas IX A SMP Negeri 2 Tolitoli,” Jurnal Kreatif Tadulako Online 4, no. 6 (2009): $272-281$.

${ }^{15}$ Lambertus, La Arapu, and Tandri Patih, "Penerapan Pendekatan Open-Ended Untuk Meningkatkan Kemampuan Berpikir Kreatif Matematik Siswa SMP,” Jurnal Pendidikan Matematika 4, no. 1 (2013): 73-82. 
kepercayaan diri siswa ${ }^{16}$. Penelitian yang dilakukan oleh Sari, Kurniawati dan Pramesti menunjukkan bahwa pendekatan open ended dapat menghasilkan kemampuan berpikir matematis yang lebih baik dibandingkan dengan pendekatan konvensional pada materi trigonometri ${ }^{17}$.

Berdasarkan beberapa pendapat dan hasil penelitian di atas menunjukkan bahwa pendekatan open ended dapat melatih dan meningkatkan kemampuan berpikir siswa sehingga guru perlu menggunakan pendekatan open ended dalam mengajar dan juga menggunakan soal dalam bentuk open ended. Rumusan masalah dalam penelitian ini adalah persepsi guru pada soal open ended yang bertujuan untuk mengetahui bagaimana persepsi guru pada soal open ended.

\section{PENDEKATAN OPEN-ENDED}

Pendekatan open ended dikembangkan di Jepang sejak tahun 1970an. Menurut Shimada pendekatan open ended berawal dari pandangan bagaimana mengevaluasi kemampuan siswa secara objektif dalam berpikir matematis tingkat tinggi ${ }^{1819}$. Guru harus bisa membuat siswa nyaman dalam keterlibatanya dalam proses pembelajaran, memberi kebebasan kepada siswa untuk menemukan solusi dari permasalahan menurut cara siswa sendiri dan diberikannya kebebasan untuk mengemukakan argumen. Kebebasan siswa dalam mengekspresikan matematika membuat siswa lebih leluasa mengembangkan kemampuan berpikir kreatif mereka masing-masing serta memperoleh pengetahuan yang lebih luas. Pendekatan open ended dapat memberi kesempatan kepada siswa untuk memperoleh pengetahuan atau pengalaman menemukan, mengenali, dan memecahkan masalah dengan beberapa teknik namun pada pendekatan open ended masalah yang diberikan adalah masalah yang bersifat terbuka atau masalah yang tidak lengkap ${ }^{20}$.

\footnotetext{
${ }^{16}$ Nenden Faridah, Isrok'atun, and Ani Nur Aeni, "Pendekatan Open-Ended Untuk Meningkatkan Kemampuan Berfikir Kreatif Dan Kepercayaan Diri Siswa,” Jurnal Pea Ilmiah 1, no. 1 (2016): 1061-1070.

17 Yunita Sari, Ira Kurniawati, and Getut Pramesti, "Penerapan Pendekatan Open Ended Dalam Pembelajaran Matematika Untuk Meningkatkan Kemampuan Berpikir Matematis Siswa Ditinjau Dari Respon Siswa Terhadap Pembelajaran Tahun Ajaran 2011 / 2012," Jurnal Pendidikan Matematika Solusi Vol 1, no. 1 (2013).

18 J.P. Becker and S. Shimada, "The Open-Ended Approach: A New Proposal for Teaching Mathematics" (2005): 87353.

19 Delyana, "Peningkatan Kemampuan Pemecahan Masalah Matematika Siswa Kelas VII Melalui Penerapan Pendekatan Open Ended."

${ }^{20}$ Sari, Kurniawati, and Pramesti, "Penerapan Pendekatan Open Ended Dalam Pembelajaran Matematika Untuk Meningkatkan Kemampuan Berpikir Matematis Siswa Ditinjau Dari Respon Siswa Terhadap Pembelajaran Tahun Ajaran 2011 / 2012.”
} 
Soal merupakan sesuatu hal yang memerlukan jawaban, hal yang harus dipecahkan $^{21}$. Pada pembelajaran soal dapat digunakn sebagai instrumen tes untuk pembelajaran. Soal soal yang digunakan sebagai instrumen tes untuk evaluasi harus lah cocok untuk mengukur kesesuaian dengan tujuan pembelajaran. Soal open-ended adalah suatu soal yang menggunakan pendekatan pembelajaran dengan menyajikan masalah yang memiliki penyelesaian benar lebih dari satu atau jawaban benar lebih dari satu sehingga siswa secara aktif mengembangkan metode, cara, atau pendekatan yang berbeda untuk menyelesaikan masalah yang diberikan ${ }^{22}$.

Mengkonstruksi dan mengembangkan soal open ended yang tepat dan baik untuk siswa dengan kemampuan yang beragam tidaklah mudah, dan memerlukan waktu yang cukup panjang. Tujuan utama pemberian masalah open-ended bukan untuk mendapatkan jawaban tetapi lebih menekankan pada cara bagaimana sampai pada jawaban sehingga siswa lebih leluasa untuk mencoba mengerjakan soal yang diberikan dengan cara mereka sendiri ${ }^{23}$. Guru dalam mengkonstruksi/membuat soal open-ended selain harus memuat soal dengan banyak cara penyelesaian, juga harus memenuhi kriteria soal open-ended. Terdapat kriteria soal open ended ${ }^{24}$ adalah sebagai berikut

1. Soal harus kaya dengan konsep matematika yang berharga

2. Level soal atau tingkatan matematika dari soal harus cocok untuk siswa

3. Soal harus mengundang pengembagan konsep matematika lebih lanjut.

a. Langkah-langkah pendekatan open ended

Apabila guru telah mengkonstruksikan suatu masalah open ended, langkah selanjutnya mengembangkan rencana pembelajaran. Menurut E. Yuliana 25 mengembangkan rencana pembelajaran dengan pendekatan open ended, sebagai berikut :

${ }^{21}$ Dendy Sugono, BAHASA INDONESIA - KAMUS (Jakarta: PUSAT BAHASA DEPARTEMEN PENDIDIKAN NASIONAL, 2008).

${ }^{22}$ Sari, Kurniawati, and Pramesti, "Penerapan Pendekatan Open Ended Dalam Pembelajaran Matematika Untuk Meningkatkan Kemampuan Berpikir Matematis Siswa Ditinjau Dari Respon Siswa Terhadap Pembelajaran Tahun Ajaran 2011 / 2012.”

23 Pratinuari, "Keefektifan Pendekatan Open-Ended Dengan Pembelajaran Kontekstual Terhadap Kemampuan Berpikir Kreatif.",

${ }^{24}$ Djahuno, "Pengembangan Soal-Soal Open-Ended Pada Pokok Bahasan Barisan Dan Deret Bilangan Di Kelas IX A SMP Negeri 2 Tolitoli.”

25 Eli Yuliana, Pengembangan Soal Open Ended Pada Pembelajaran Matematika Untuk Mengidentifikasi Kemampuan Berfikir Kreatif Siswa, 2015. 
1. Tulislah respon siswa yang diharapkan.

Hal ini diperlukan mengingat kemampuan siswa terbatas dalam mengekspresikan ide dan pikirannya. Antisipasi guru membuat kemungkinan respon yang dikemukakan siswa menjadi penting dalam upaya mengarahkan dan membantu siswa memecahkan masalah sesuai dengan cara kemampuannya.

2. Tujuan dari masalah yang diberikan kepada siswa harus jelas.

Guru harus benar-benar memahami peran masalah dalam keseluruhan rencana pembelajaran. Apakah masalah yang diberikankepada siswa diperlukan sebagai pengenalan konsep baru atau dalam merangkum kegiatan belajar.

3. Sajikan masalah semenarik mungkin bagi siswa.

Masalah harus membangkitkan keingintahuan serta semangat intelektual siswa.

4. Berikan waktu kepada siswa untuk mengeksplorasi masalah.

Terkadang waktu yang dialokasikan tidak cukup dalam menyajikan masalah, memecahkannya, mendiskusikan cara penyelesaian dan merangkum dari apa yang telah dipelajari siswa. Karena itu guru harus memberikan waktu yang cukup kepada siswa untuk mengeksplorasi masalah. Berdiskusi aktif antara sesama siswa dan guru merupakan interaksi yang sangat penting dalam pembelajaran dengan menggunakan pendekatan open ended

b. Keunggulan dan kelemahan pendekatan open ended

Menurut $^{26}$, pendekatan open ended memiliki beberapa keunggulan antara lain :

a) Siswa berpartisipasi lebih aktif dalam pembelajaran dan sering mengekspresikan idenya.

b) Siswa memiliki kesempatan lebih banyak dalam memanfaatkan pengetahuan dan keterampilan matematika secara komprehensif. Karena terdapat banyak jawaban berbeda, maka siswa bebas memilih cara mereka untuk memperoleh jawaban yang unik.

c) Siswa dengan kemampuan matematika rendah dapat merespon permasalahan dengan cara mereka sendiri.

d) Siswa termotivasi untuk memberikan bukti atau penjelasan.

e) Siswa memiliki pengalaman banyak untuk menemukan sesuatu dalam menjawab permasalahan.

26 Firdaus, As'ari, and Qohar, "Meningkatkan Kemampuan Berpikir Kreatif Matematis Siswa Sma Melalui Pembelajaran Open Ended Pada Materi Spldv." 
Disamping keunggulan terdapat pula kelemahan pendekatan open ended, diantaranya:

a. Membuat dan menyiapkan masalah matematika bermakna bagi siswa bukanlah pekerjaan yang mudah.

b. Mengemukakan masalah yang langsung yang dapat dipahami siswa sangat sulit sehingga banyak siswa yang mengalami kesulitan bagaimana merespon permasalah yang diberikan.

c. Siswa dengan kemampuan tinggi bisa merasa ragu dan mencemaskan jawaban mereka.

Mungkin ada sebagian siswa yang merasa bahwa kegiatan belajar mereka tidak menyenangkan karena kesulitan yang mereka hadapi.

\section{METODE}

Pendekatan yang dilakukan dalam penilitian ini adalah pendekatan kualitatif. Pendekatan kualitatif adalah penelitian pendekatan yang menjelajahi masalah dan mengembangkan pemahaman secara rinci mengenai fenomena dengan mengumpulkan data berdasarkan kata-kata dari sejumlah kecil individu sehingga dapat dianalisis secara deskriptif kemudian menafsirkan makna temuan ${ }^{27}$. Penelitian ini akan dilakukan kepada empat guru matematika SMK dan dilaksanakan pada 13 Januari 2017. Topik penelitian yang akan diteliti adalah persepsi guru mengenai soal open ended.

Subjek penelitian ini adalah empat orang guru matematika SMK sedangkan yang menjadi objek penelitian ini adalah persepsi guru mengenai soal open ended. Data yang akan dipakai dalam penelitian ini adalah persepsi guru pada soal open ended selama mengajar sedangkan sumber data persepsi guru mengenai soal open ended didapat dari guru yang diwawancarai dan diberikan angket.

Teknik pengumpulan data yang dipilih untuk memecahkan masalah penelitian adalah angket yang digunakan untuk memperoleh data mengenai kesulitan guru dalam pembuatan soal open ended. Wawancara digunakan untuk mendukung data yang diperoleh dari angket mengenai kesulitan guru dalam pembuatan soal open ended.

Instrumen yang digunakan pada penelitian ini adalah instrumen primer yang merupakan peneliti sendiri karena berperan sebagai pencari dan pengumpul data dari sumber

27 John W Creswell, Educational Research: Planning, Conducting, and Evaluating Quantitative and Qualitative Research, Educational Research, vol. 4, 2012. 
data sedangkan instrumen sekunder yakni lembar angket kesulitan guru dalam pembuatan soal open ended dan pedoman wawancara agar wawancara dapat terlaksana dengan baik.

Lembar angket terdiri dua jenis yaitu tertutup dan terbuka. Lembar angket tertutup digunakan untuk mengukur dan mengklasifikasikan kesulitan guru dalam pembuatan soal open ended sedangkan lembar angket terbuka digunakan untuk mendukung hasil dari klasifikasi angket tertutup.

Pedoman wawancara diperlukan agar wawancara terlaksana dengan baik sehingga dapat diperoleh data yang dibutuhkan oleh peneliti mengenai kesulitan guru dalam pembuatan soal open ended. Teknik analisis data yang digunakan adalah analisis data kualitatif deskriptif.

\section{PEMBAHASAN}

Peneliti mewawancarai empat orang guru matematika. Berikut hasil wawancara terhadap guru matematika mengenai persepsi guru pada soal open ended. Guru pertama mengatakan bahwa soal open ended adalah soal yang memiliki banyak solusi sehingga dapat menstimulasi siswa untuk berpikir kreatif dan bernalar. Tujuan dari pengembangan soal open ended agar siswa dapat berlatih mengerjakan soal non rutin sehingga siswa tidak kaget jika ujian diberikan soal non rutin. Pada penerapan pengembangannya, guru mengalami kendala yaitu kesulitan dalam menemukan topik yang mudah dikembangkan selain itu siswa sudah terbiasa mengerjakan soal-soal rutin. Siswa pun masih mengalami kesulitan dalam mengerjakan soal-soal rutin sehingga ketika mengerjakan soal-soal non rutin siswa mengalami banyak kesulitan karena kurang mampu memahami masalah padahal soal open ended dapat dikerjakan dengan cara yang sederhana.

Hasil wawancara dengan guru kedua, soal open ended adalah soal yang bermakna bagi siswa dimana terdapat banyak jawaban. Guru mengembangkan soal open ended dan dalam penerapannya siswa yang memiliki kemampuan tinggi merasa khawatir terhadap jawabannya karena terdapat banyak penafsiran dalam menjawab soal. Kendala guru dalam menyiapkan topik yang bermakna dalam soal open ended bagi siswa membutuhkan waktu yang lama.

Hasil wawancara dengan guru ketiga, guru tidak mengembangkan maupun menggunakan soal open ended dikarenakan siswa terbiasa mengerjakan soal-soal rutin dan menyelesaikan sesuai dengan contoh soal selain itu guru harus menyiapkan rubrik penilaian 
sesuai dengan kunci jawaban yang banyak serta membutuhkan banyak tenaga untuk mengoreksi berbagai jawaban siswa yang berbeda jika menggunakan soal open ended.

Hasil wawancara guru keempat, guru belum pernah menggunakan soal open ended dalam pembelajaran dikarenakan tidak semua optimal digunakan dalam soal open ended serta dibutuhkan waktu lebih banyak dan tenaga dalam mengoreksi hasil pengerjaan soal open ended. Guru hanya pernah menggunakan dan mengembangkan soal yang memiliki banyak cara pengerjaan. Bagi guru cukup mengembangkan soal banyak cara namun memiliki jawaban tunggal lebih mudah dikembangkan dan dapat digunakan untuk mengukur pemahaman dan kreativitas siswa dalam menyelesaikan masalah.

\section{KESIMPULAN}

Berdasarkan hasil wawancara di atas dapat disimpulkan bahwa terdapat dua guru yang pernah mengembangkan soal open ended dan dua orang guru belum pernah mengembangkan soal open ended. Kendala dari guru yang pernah mengembangkan adalah kesulitan dalam menemukan topik yang bermakna serta mudah untuk dikembangkan. Kendala bagi guru yang belum pernah mengembangkan adalah guru belum percaya kepada siswa karena siswa masih mengalami kesulitan dalam mengerjakan soal mudah serta guru masih memiliki minat yang rendah terhadap pengembangan dan penggunaan soal open ended. 


\section{DAFTAR PUSTAKA}

Becker, J.P., and S. Shimada. "The Open-Ended Approach: A New Proposal for Teaching Mathematics" (2005): 87353.

Creswell, John W. Educational Research: Planning, Conducting, and Evaluating Quantitative and Qualitative Research. Educational Research. Vol. 4, 2012.

Delyana, Hafizah. "Peningkatan Kemampuan Pemecahan Masalah Matematika Siswa Kelas VII Melalui Penerapan Pendekatan Open Ended.” Lemma Vol 2, no. 1 (2015): 26-34.

Djahuno, Saniah. "Pengembangan Soal-Soal Open-Ended Pada Pokok Bahasan Barisan Dan Deret Bilangan Di Kelas IX A SMP Negeri 2 Tolitoli.” Jurnal Kreatif Tadulako Online 4, no. 6 (2009): 272-281.

Faridah, Nenden, Isrok'atun, and Ani Nur Aeni. "Pendekatan Open-Ended Untuk Meningkatkan Kemampuan Berfikir Kreatif Dan Kepercayaan Diri Siswa." Jurnal Pea Ilmiah 1, no. 1 (2016): 1061-1070.

Firdaus, Abdur Rahman As'ari, and Abd Qohar. "Meningkatkan Kemampuan Berpikir Kreatif Matematis Siswa Sma Melalui Pembelajaran Open Ended Pada Materi Spldv." Jurnal Pendidikan 1, no. 2 (2016): 227-236.

Hashimoto, Yoshihiko. "The Methods of Fostering Creativity through Mathematical Problem Solving.” ZDM - International Journal on Mathematics Education 29, no. 3 (1997): 8687.

Kemendikbud. "Permendikbud Nomor 70 Tahun 2013 Tentang Kerangka Dasar Dan Struktur Kurikulum Sekolah Menenggah Kejuruan/Madrasah Aliyah Kejuruan," no. Standar Penilaian Pendidikan (2016): 1-234.

Lambertus, La Arapu, and Tandri Patih. "Penerapan Pendekatan Open-Ended Untuk Meningkatkan Kemampuan Berpikir Kreatif Matematik Siswa SMP." Jurnal Pendidikan Matematika 4, no. 1 (2013): 73-82.

Mahmudi, Ali. "Mengukur Kemampuan Berpikir Kreatif Matematis." In Konferensi Nasional Matematika XV UNIMA Manado. (2010).

Mann, Eric L. "Creativity: The Essence of Mathematics." Journal for the Education of the Gifted 30, no. 2 (2006): 236-260.

Muhsinin, Ummil. "Pendekatan Open Ended Pada Pembelajaran.” Edu-Math 4, no. 1 (2013): $46-59$.

Ninomiya, Hiro, and Panpiti Pusri. "The Study of Open-Ended Approach in Mathematics Teaching Using Jigsaw Method." A Case Study of the Water Beaker Problem 64, no. 2 (2015): 11-22.

Osana, Helena P., Guy L. Lacroix, Bradley J. Tucker, and Chantal Desrosiers. "The Role of Content Knowledge and Problem Features on Preservice Teachers' Appraisal of Elementary Mathematics Tasks." Journal of Mathematics Teacher Education 9, no. 4 (2006): 347-380.

Pehkonen, Erkki. "Fostering of Mathematical Creativity" (1983): 63-67.

Pratinuari, Karina. “Keefektifan Pendekatan Open-Ended Dengan Pembelajaran Kontekstual 
Terhadap Kemampuan Berpikir Kreatif.” Ujme 2, no. 1 (2013): 105-113.

Runcho, Mark A. "Creativity as an Educational Objective for Disadvantaged Students." The National Research Center on The Gifted and Talented, no. 9306 (1993).

Sari, Yunita, Ira Kurniawati, and Getut Pramesti. "Penerapan Pendekatan Open Ended Dalam Pembelajaran Matematika Untuk Meningkatkan Kemampuan Berpikir Matematis Siswa Ditinjau Dari Respon Siswa Terhadap Pembelajaran Tahun Ajaran 2011 / 2012.” Jurnal Pendidikan Matematika Solusi Vol 1, no. 1 (2013).

Sugono, Dendy. BAHASA INDONESIA - KAMUS. Jakarta: PUSAT BAHASA DEPARTEMEN PENDIDIKAN NASIONAL, 2008.

Yuliana, Eli. Pengembangan Soal Open Ended Pada Pembelajaran Matematika Untuk Mengidentifikasi Kemampuan Berfikir Kreatif Siswa, 2015. 